\title{
Association of CAPN1 and GH genes with productivity traits in Kazakh Whiteheaded cattle
}

\author{
V Plakhtukova $^{1}$, M I Selionova ${ }^{1}$, M Yu Gladkikh ${ }^{1, *}$, and O V Kuznetsova ${ }^{1}$ \\ ${ }^{1}$ Russian State Agrarian University - Moscow Timiryazev Agricultural Academy, Timiryazevskaya \\ St., 49, 127550, Moscow, Russia
}

\begin{abstract}
The Kazakh Whiteheaded cattle was developed by crossing local breeds with the Hereford breed in Kazakhstan in the 30s of the last century. This breed is adapted to arid conditions of extreme continental climate. The goal of the investi-gations was the assessment of the genetic structure of the Kazakh Whiteheaded breed based on the genes of calpain $(C A P N 1)$ and somatotropic hormone $(G H)$ and analysis of the association of genotypes for these genes with productivity traits. The main argument for this aim is research works illustrated that both genes could affect on meat productivity traits in other breeds of cattle. 352 blood samples from representatives of Kazakh Whiteheaded animals of different sex and age groups were genotyped for the CAPNI and GH loci. As a result, it was firstly proved that Kazakh Whiteheaded animals, who are $C C$ homozygosis at the CAPN1 locus and $V V$ homozygosis at the $G H$ locus, reliably exceed animals without $C$ and $\mathrm{V}$ alleles on the productivity traits such as milk production, average daily body weight gain, and pre-slaughter body weight, slaughter weight, carcass weight, flesh weight, chemical composition and histological characteristics of meat. It was also shown that the frequencies of the desired alleles and genotypes of these loci are rather low - the frequency of the $C$ allele was $0.11-0.17$, and the frequency of the $C C$ genotype was $0.03-0.06$ in different age and sex groups; the frequency of the $V$ allele was $0.19-0.40$, and the frequency of the $V V$ genotype was 0.03-0.31. Thus, planning selection for Kazakh Whiteheaded cattle, it would be useful to take into account the assessment of ani-mal genotypes at the $C A P N 1$ and $G H$ loci to increase the proportion of animals with the desired genotypes.
\end{abstract}

\section{Introduction}

Evaluation of animal genotypes by genes associated with the productivity traits is a convenient, accessible and in-demand method to predict the productive qualities of beef cattle at an early age [1-2]. In this regard, studies aimed at identifying the polymorphism of loci associated with the quantitative and qualitative characteristics of muscle and adipose

\footnotetext{
* Corresponding author: marianna1001@ yandex.ru
} 
tissue, and assessing the frequencies of the desired alleles and genotypes in herds are becoming increasingly important [3-5].

Numerous studies have shown the contribution of many genes - MSTN, CAPN, CAST, $G H, L E P, T G, F A B P, R O R C, D G A T I, S C D$ - in meat productivity traits of foreign and domestic breeds [2, 6-15]. The association of calpain gene (CAPN1) polymorphism, the product of which controls the weakening of connections between the eye muscle areas and creates conditions for a uniform distribution of intramuscular fat between the fibres, has been demonstrated for many beef cattle breeds $[7,16]$. One of the key regulators of animal growth is somatotropic hormone, which also plays an important role in carbohydrate-fat metabolism [17-20]. Therefore, the identification of polymorphism in the genes of calpain $C A P N 1$ and growth hormone $G H$ and the relationship of genotypes for these genes with the meat productivity will improve the selection programs progress.

The goal of our investigation was the estimation of CAPN1 and GH genes polymorphism with certain productivity traits of Kazakh Whiteheaded cattle and identification of desired genotypes for their usage in selection to improve meat production and quality.

\section{Material and methods}

Blood samples of 352 Kazakh Whiteheaded animals from Collective farm «Gigant» (Stavropolskiy region) were taken. There were sires $(\mathrm{n}=35)$ and dams $(\mathrm{n}=160)$, heifers $(\mathrm{n}$ $=64)$ and young bulls $(\mathrm{n}=93)$. The farm is breeding organization. Mother-stock is kept on the pasture during the whole year. Weaning of calves take place at 240-day age.

The fattening of bulls is carried out according to rations calculated for an average daily gain (at least $1000 \mathrm{~g}$ ). The bulls are kept loose housing on a non-removable bed; in summer animals were provided with round-the-clock access to out-door, in winter - only during the daylight.

Extraction of DNA from blood samples was carried out with the kit «DIAtomtmDNAPrep» in accordance with the protocol of the company «Isogen» (Russia).

GH gene polymorphism was determined by PCR-RFLP using the GenePakPCRCore kits («Isogen») in a volume of $20 \mu \mathrm{L}$ containing $5 \mu \mathrm{L}$ of DNA sample, $10 \mu \mathrm{L}$ of PCR solvent and $1.0 \mu \mathrm{L}$ of primers each: GH-F: 5'- GCT-GCT-CCT-GAG-CCT-TCG-3 'and GH-R: 5'-GCG-GCG-GCA-CTT-CAT-GAC-CCT-3'. Products of amplification were digested with the restriction enzyme Alu I.

Polymorphism for the CAPN1 gene was determined on ANK-32 (nucleic acid analyzer) using the «CAPN1» kit, including allele-specific probes: 5'-AGC-AGC-CCA-CCA-TCAGAG-AAA-3 'and 5' -TCA-GCT-GGT-TCG-GCA-GAT-3 '(«Syntol», Russia).

The work was carried out in the laboratory of immunogenetics and DNA technologies, VNIIOK, "North Caucasian FNATs".

The concentration of fatty acids (FA) in blood plasma was determined by gas-liquid chromatography in the form of methyl esters on a Kristall 200 gas chromatograph with an HP-FFAP $50 \mathrm{~m} 0.32 \mathrm{~mm} 0.5 \mathrm{pm}$ capillary column (USA). FA identification was carried out on Sigma and Fluka standards. The quantitative determination of FA was carried out with Chromatek Analyst software.

The blood test included total protein and its fractions, glucose, calcium, phosphorus and magnesium. The analysis was carried out on automatic biochemical analyzers according to the methods described in the department of veterinary medicine at All-Russian Research Institute for Sheep and Goat Breeding (VNIIOK). The milk production of cows was estimated by the live weight of their offspring at the age of 205 days. To assess the conformation of bulls and heifers, 6 animals of each genotype. Measurements of exterior traits were carried out with measuring stick, tape and compasses. Also body conformation 
indexes were calculated for each animal. The live weight of bulls at birth and weaning was taken for all genotyped animals $(\mathrm{n}=93)$, at 12 months of age - for 6 animals of each genotype $(\mathrm{n}=36)$. The live weight of heifers was taken at birth, weaning, at 15 -month and 18 -month age for all genotyped animals $(n=64)$. The live weight was determined by individual weighing with an electronic scale with an accuracy of $0.1 \mathrm{~kg}$.

To analyze the chemical composition of meat and its histological characteristics, animals were slaughtered at 12-month age according to the standard methods $(1977,1984)$ : three animals of each genotype were used. Analysis of the chemical composition of samples of $\mathrm{m}$. Longissimus dorsi included the determination of moisture, protein and fat (GOST 9793 "Meat and meat products. Methods for the determination of moisture", GOST 25011 "Meat and meat products. Methods for the determination of protein", GOST 23042 "Meat and meat products. Methods for determination of fat"). For histological analysis of eye muscle area, the number and diameter of muscle fibers, and the proportion of muscle and connective tissues were determined. These studies were carried out in accordance with GOST 19496-2013 "Meat and meat products. Method of histological examination". Allele and genotype frequencies, observed and expected heterozygosity, and the Hardy-Weinberg equilibrium were estimated with the GenAlEx 6.5 program. The results were analyzed statistically with Microsoft Excel. The significance of the differences was calculated by the Student's test with the following significance levels: * $-\mathrm{P}<0,05 ; * *-\mathrm{P}<0,01$; *** $\mathrm{P}<0,001$.

\section{Results and discussion}

$C A P N 1$ gene is represented by two alleles $C$ and $G$, the $G H$ gene is represented also by two alleles $V$ and $L$. Frequencies of alleles and genotypes for the CAPN1 and GH genes are shown in tables 1 and 2, respectively.

Table 1. Frequencies of alleles and genotypes for the CAPN1 gene in Kazakh Whiteheaded cattle of different sex and age groups.

\begin{tabular}{|c|c|c|c|c|c|}
\hline \multirow{2}{*}{ Sex and age group } & \multicolumn{2}{|c|}{ Alleles } & \multicolumn{3}{c|}{ Genotypes } \\
\cline { 2 - 6 } & $C$ & $G$ & $C C$ & $C G$ & $G G$ \\
\hline Sires, $\mathrm{n}=35$ & 0,11 & 0,89 & 0,03 & 0,17 & 0,80 \\
\hline Dams, $\mathrm{n}=106$ & 0,14 & 0,86 & 0,04 & 0,19 & 0,77 \\
\hline Young bulls, $\mathrm{n}=93$ & 0,13 & 0,87 & 0,06 & 0,13 & 0,81 \\
\hline Heifers, $\mathrm{n}=64$ & 0,17 & 0,83 & 0,06 & 0,22 & 0,72 \\
\hline
\end{tabular}

The frequencies of the $C C, C G$, and $G G$ genotypes for the $C A P N 1$ gene in all age and sex groups are in accordance with the Hardy-Weinberg equilibrium (chi-square test, $\mathrm{p}>$ $0.05)$.

Table 2. Frequencies of alleles and genotypes for the $G H$ gene in Kazakh Whiteheaded cattle of different sex and age groups.

\begin{tabular}{|c|c|c|c|c|c|}
\hline \multirow{2}{*}{ Sex and age group } & \multicolumn{2}{|c|}{ Alleles } & \multicolumn{3}{c|}{ Genotypes } \\
\cline { 2 - 6 } & $V$ & $L$ & $V V$ & $L V$ & $L L$ \\
\hline Sires, $\mathrm{n}=35$ & 0,19 & 0,81 & 0,03 & 0,31 & 0,66 \\
\hline Dams, $\mathrm{n}=106$ & 0,30 & 0,70 & 0,16 & 0,28 & 0,56 \\
\hline Young bulls, $\mathrm{n}=93$ & 0,40 & 0,60 & 0,31 & 0,18 & 0,51 \\
\hline Heifers, $\mathrm{n}=64$ & 0,25 & 0,75 & 0,11 & 0,28 & 0,61 \\
\hline
\end{tabular}


The distributions of $V V, L V$, and $L L$ genotypes for the $G H$ gene among brood bulls and heifers correspond to the Hardy-Weinberg equilibrium (chi-square is 4.13 and 4.00, respectively). Moreover, their distributions of genotypes are the same (chi-square is 2.69 with $\mathrm{p}>0,05$ ). Among dams and young bulls, the Hardy-Weinberg equilibrium are not observed (chi-square is 11.40 and 35.86, respectively). Among dams, there is a significant deficiency of heterozygotes ( 0.28 compared to the expected frequency of 0.42$)$, among young bulls - also a deficiency, with an expected frequency of $L V$ heterozygotes of 0.48 , the observed frequency of heterozygotes is only 0.18 .

Thus, we can conclude that genotyping for the CAPN1 and $G H$ genes of the Kazakh Whiteheaded breed, polymorphism for these genes was revealed, each gene is represented by two alleles. The low frequency of $C(C A P N 1)$ and $V(G H)$ alleles, which in many studies have been shown as desirable for selection, has been established.

Reproductive traits and milk production of Kazakh Whiteheaded cows of different genotypes for the $C A P N 1$ and $G H$ genes. No significant differences in the reproductive traits of cows of different genotypes were found. In total, 159 (99.3\%) out of 160 cows calved, 160 calves were received; before weaning, 157 calves were raised ( 93 bulls and 64 heifers).

The milk production of cows with $C C$ genotypes for the $C A P N 1$ gene and $V V$ for the $G H$ gene is significantly higher than that of cows who did not have the desired alleles (table 3 ). The difference between the live weight of $C C$ - and $G G$-dams offspring at the 205-day age was $12.7 \mathrm{~kg}$, or $6.8 \%(\mathrm{P}<0.05)$, the average daily gain of $C C$-dams offspring is significantly higher by $62.8 \mathrm{~kg}$ than that of offspring of the $G G$-dams.

Table 3. Milk production characteristics of Kazakh Whiteheaded cows with different genotypes.

\begin{tabular}{|c|c|c|c|c|c|}
\hline \multirow{2}{*}{ Genotype } & \multirow{5}{*}{ Body weight, kg Average weight, kg } \\
\cline { 3 - 6 } & & At birth & 205 days & $\begin{array}{c}\text { At weaning } \\
\text { (240 days) }\end{array}$ & $\begin{array}{c}\text { Annual } \\
\text { daily gain, g }\end{array}$ \\
\hline \multicolumn{7}{|c|}{$C A P N 1$} \\
\hline$C C$ & $522,6 \pm 2,60^{*}$ & $28,1 \pm 0,21$ & $202,1 \pm 3,5^{*}$ & $226,0 \pm 4,6$ & $824,6 \pm 1,92^{*}$ \\
\hline$C G$ & $519,7 \pm 1,09$ & $27,9 \pm 0,18$ & $197,7 \pm 5,4$ & $217,0 \pm 6,5$ & $787,6 \pm 0,72$ \\
\hline$G G$ & $516,4 \pm 1,19$ & $27,6 \pm 0,16$ & $189,4 \pm 5,2$ & $210,4 \pm 5,2$ & $761,8 \pm 0,85$ \\
\hline \multicolumn{7}{|c|}{$G H$} \\
\hline$V V$ & $521,5 \pm 2,77^{*}$ & $28,3 \pm 0,11$ & $201,3 \pm 6,5^{*}$ & $228,0 \pm 7,5^{*}$ & $832,1 \pm 1,65^{*}$ \\
\hline$L V$ & $519,2 \pm 2,12$ & $27,9 \pm 0,18$ & $196,9 \pm 5,3$ & $216,2 \pm 4,5$ & $784,6 \pm 0,92$ \\
\hline$L L$ & $518,1 \pm 1,97$ & $27,6 \pm 0,12$ & $191,0 \pm 4,5$ & $209,2 \pm 6,1$ & $756,7 \pm 0,71$ \\
\hline
\end{tabular}

The same situation is observed comparing the offspring of cows with the desired $V$ allele of the $G H$ gene and offspring of cows not having this allele. In the offspring of cows with $V V$ and $L V$ genotypes, the average weight at 205 days was $199.1 \mathrm{~kg}$, while in the offspring of cows of the $L L$ genotype $-191.0 \mathrm{~kg}$, or $4.1 \%$ less. The average weight of the offspring of $V V$ cows was significantly higher by $10.3 \mathrm{~kg}$, or $5.4 \%$ of the average weight of the offspring of cows with the $L L$ genotype, there was a significant difference $(\mathrm{P}<0,05)$.

At 8- and 12-month age, homozygous $C C$ (CAPN1 gene) and $V V$ ( $G H$ gene) animals had a larger weight. Thus, bulls with the $C C$ genotype were superior to their peers with the $G G$ genotype by $29.7 \mathrm{~kg}$, or $13.8 \%(\mathrm{P}<0.01)$ at the 8 -month age, and by $24.3 \mathrm{~kg}$, or $6.9 \%$ $(\mathrm{P}<0.05)$ at the 12-month age. The weight of $C C$ homozygotes heifers at 8 - and 12-month age is $16.2 \mathrm{~kg}$ higher, or $8.3 \%(\mathrm{P}<0.05)$, and $22.8 \mathrm{~kg}$, or $7.9 \%(\mathrm{P}<0.05)$, respectively, than that of $G G$ homozygotes. The differences between the weight of $V V$ homozygotes $(G H$ gene) at 8 - and 12-month age of young bulls were $34.5 \mathrm{~kg}(14.6 \% ; \mathrm{P}<0.01), 24,8 \mathrm{~kg}(6.9 \%$; 
$\mathrm{P}<0.01)$, in heifers $-10.2 \mathrm{~kg}(5.2 \% ; \mathrm{P}<0.05), 18.1 \mathrm{~kg}(6.3 \%$; $<00,05)$, respectively (tables 4 and 5).

Table 4. Dynamics of Kazakh Whiteheaded young bulls weight of different genotypes (CAPN1 and $G H)$.

\begin{tabular}{|c|c|c|c|c|c|c|}
\hline \multirow{2}{*}{ Traits } & \multicolumn{3}{|c|}{ CAPNI } & \multicolumn{3}{|c|}{$G H$} \\
\hline & $C C$ & $C G$ & $G G$ & $V V$ & $L V$ & $L L$ \\
\hline & & & & & & \\
\hline $\begin{array}{r}\text { Weight, kg: } \\
\text { At birth }\end{array}$ & $\begin{array}{c}28,1 \\
\pm 0,21 *\end{array}$ & $\begin{array}{r}27,9 \\
\pm 0,18 \\
\end{array}$ & $\begin{array}{c}27,6 \\
\pm 0,16 \\
\end{array}$ & $\begin{array}{c}28,3 \\
\pm 0,11 *\end{array}$ & $\begin{array}{r}27,9 \\
\pm 0,18 \\
\end{array}$ & $\begin{array}{r}27,6 \\
\pm 0,12 \\
\end{array}$ \\
\hline $\begin{array}{l}\text { At 8-month } \\
\text { age } \\
(\mathrm{n}=93)\end{array}$ & $\begin{array}{r}245,5 \\
\pm 4,6^{* *}\end{array}$ & $\begin{array}{c}240,6 \\
\pm 6,5\end{array}$ & $\begin{array}{l}215,8 \\
\pm 5,2\end{array}$ & $\begin{array}{c}248,9 \\
\pm 7,5^{* *}\end{array}$ & $\begin{array}{l}238,5 \\
\pm 4,5^{*}\end{array}$ & $\begin{array}{c}214,4 \\
\pm 6,1\end{array}$ \\
\hline $\begin{array}{l}\text { At 12-month } \\
\text { age } \\
(\mathrm{n}=36)\end{array}$ & $\begin{array}{l}374,2 \\
\pm 5,1 *\end{array}$ & $\begin{array}{c}368,9 \\
\pm 3,6\end{array}$ & $\begin{array}{c}349,9 \\
\pm 4,1\end{array}$ & $\begin{array}{c}382,7 \\
\pm 4,7 * *\end{array}$ & $\begin{array}{c}373,8 \\
\pm 4,2\end{array}$ & $\begin{array}{c}357,9 \\
\pm 5,2\end{array}$ \\
\hline $\begin{array}{l}\text { Annual daily } \\
\text { gain, g }\end{array}$ & $\begin{array}{c}948,4 \\
\pm 92,4^{*}\end{array}$ & $\begin{array}{l}934,2 \\
\pm 72,6\end{array}$ & $\begin{array}{l}883,2 \\
\pm 85,4\end{array}$ & $\begin{array}{c}969,5 \\
\pm 65,4^{*}\end{array}$ & $\begin{array}{l}948,1 \\
\pm 92,7\end{array}$ & $\begin{array}{l}905,4 \\
\pm 71,3\end{array}$ \\
\hline
\end{tabular}

Table 5. Dynamics of Kazakh Whiteheaded heifers weight of different genotypes (CAPN1 and GH).

\begin{tabular}{|c|c|c|c|c|c|c|}
\hline \multirow{2}{*}{ Traits } & \multicolumn{3}{|c|}{$C A P N 1$} & \multicolumn{3}{c|}{$G H$} \\
\cline { 2 - 7 } & $C C$ & $C G$ & $G G$ & $V V$ & $L V$ & $L L$ \\
\hline Weight, kg: & 27,9 & 26,1 & 25,6 & 26,9 & 27,1 & 27,6 \\
At birth & $\pm 0,57$ & $\pm 0,37$ & $\pm 0,65$ & $\pm 0,68$ & $\pm 0,43$ & $\pm 0,34$ \\
\hline At 8-month & $209,9^{*}$ & 200,8 & 193,7 & $206,7^{*}$ & 201,2 & 196,5 \\
age & $\pm 2,6$ & $\pm 1,7$ & $\pm 1,4$ & $\pm 2,7$ & $\pm 1,9$ & $\pm 1,8$ \\
\hline At 12-month & $308,5^{*}$ & 299,9 & 285,7 & $305,7^{*}$ & 300,8 & 287,6 \\
age & $\pm 4,8$ & $\pm 4,2$ & $\pm 3,8$ & $\pm 6,4$ & $\pm 3,4$ & $\pm 3,2$ \\
\hline At 18-month & $357,5^{* *}$ & $339,9,7$ & 335,7 & $356,7^{*}$ & 341,8 & 344,9 \\
age & $\pm 4,8$ & $\pm 4,2$ & $\pm 3,8$ & $\pm 6,4$ & $\pm 3,4$ & $\pm 3,2$ \\
\hline Annual daily gain, & $610,3^{*}$ & 581,1 & 574,2 & $610,7 *$ & 582,8 & 587,9 \\
g & $\pm 51,7$ & $\pm 42,2$ & $\pm 38,1$ & $\pm 42,4$ & $\pm 38,3$ & $\pm 41,1$ \\
\hline \multicolumn{7}{|c|}{$* P<0,05, * * P<0,01$ compared CAPNI-CC-GG; GH-VV- LL. } \\
\hline
\end{tabular}

Thus, the presence of the desired alleles in the homozygous state promoted higher growth vigor in young bulls and heifers during the studied periods of ontogenesis.

There were no significant differences in body measurements in both young bulls and heifers of different genotypes.

In all examined animals, blood biochemical parameters were within the physiological norm. However, some signs revealed differences between animals of different genotypes. Thus, in young bulls with genotypes $C C$ and $V V$, which had the number of erythrocytes in the blood 6.42 and $7.2 \times 1012$ / L, respectively, were significantly differed from the number of red blood cells in young bulls with genotypes $G G$ and $L L(\mathrm{P}>0.05)$. With a higher number of erythrocytes in the blood of young bulls, a higher concentration of hemoglobin was also observed. The number of leukocytes, protein and glucose level in the blood in the $C C-C A P N 1$ and $V V-G H$ calves significantly exceeded these indicators in $G G-C A P N 1$ and $L L-G H(\mathrm{P}<0.05)$. There were no significant differences in the level of calcium, phosphorus and magnesium between animals of different genotypes.

The qualitative composition of fatty acids in young bulls of different genotypes was identical. However, in terms of quantitative characteristics, the genotypes were differed. In homozygous $C C$ and $V V$ young bulls, the proportion of unsaturated fatty acids in blood plasma was higher than in homozygous $G G$ and $L L$ animals, respectively, by $6.3 \%$ and 
$7.1 \%$. This also affected the lower values of the lipid metabolism directional index in the $C C$ and $V V$ genotypes - 0.92 and 1.00 versus 1.04 and 1.13 in the $G G$ and $L L$ genotypes. In homozygotes $C C$ and $V V$ and heterozygotes $C G$ and $L V$, the total amount of lipids and glucose in the blood is lower by an average of $11.2 \%$ than in $G G$ - and $L L$-homozygotes (table 6). The level of cholesterol in the blood of animals of these genotypes is on average $12.8 \%$ higher.

Table 6. The metabolites level of energy metabolism in the blood plasma of young Kazakh Whiteheaded bulls of different genotypes.

\begin{tabular}{|c|c|c|c|c|c|c|c|}
\hline \multirow{4}{*}{ تั๊ } & \multirow{4}{*}{ Genotype } & \multicolumn{6}{|c|}{ Indicators } \\
\hline & & \multirow{3}{*}{$\begin{array}{l}\text { Lipids, } \\
\text { g/l }\end{array}$} & \multirow{3}{*}{$\begin{array}{c}\text { Cholesterin, } \\
\text { mmol / } 1\end{array}$} & \multirow{3}{*}{$\begin{array}{l}\text { Glucose, } \\
\text { mmol / L }\end{array}$} & \multicolumn{3}{|c|}{ Amount of fatty acids, $\%$} \\
\hline & & & & & & & \\
\hline & & & & & Saturated & $\begin{array}{c}\text { Mono } \\
\text {-unsaturated }\end{array}$ & $\begin{array}{c}\text { Poly- } \\
\text { unsaturated }\end{array}$ \\
\hline \multirow{3}{*}{$\begin{array}{l}\bar{z} \\
\bar{u} \\
\bar{u}\end{array}$} & $C C$ & $3,96 \pm 0,21 *$ & $4.78 \pm 0,33 *$ & $3,37 \pm 0,31$ & 48,07 & 28,28 & 23,63 \\
\hline & $C G$ & $4,02 \pm 0,23$ & $4,41 \pm 0,22$ & $3,68 \pm 0,22$ & 50,64 & 26,70 & 22,40 \\
\hline & $G G$ & $4,42 \pm 0,17$ & $3,92 \pm 0,17$ & $4,02 \pm 0,19$ & 50,88 & 27,04 & 21,78 \\
\hline \multirow{3}{*}{ ত্ড } & $V V$ & $4,08 \pm 0,28 *$ & $5,03 \pm 0,24 *$ & $3,74 \pm 0,37$ & 49,88 & 25,01 & 24,81 \\
\hline & $L V$ & $4,65 \pm 0,33$ & $4,87 \pm 0,18$ & $3,91 \pm 0,18^{*}$ & 49,87 & 25,22 & 24,84 \\
\hline & $L L$ & $4,82 \pm 0,17$ & $4,33 \pm 0,31$ & $4,26 \pm 0,22$ & 52,90 & 24,16 & 22,29 \\
\hline & & $* P<0,05$ & $* * P<0,01 c$ & ompared $C A$ & $-C C-G$ & $H-V V-L L$. & \\
\hline
\end{tabular}

Thus, the obtained data indicate that the intensity of lipid metabolism in young Kazakh Whiteheaded bulls is different in individuals of different genotypes for the CAPN1 and GH genes. It can be assumed that animals with the desired $\mathrm{C}$ and $\mathrm{V}$ alleles in the homo- and heterozygous state used the energy resources of the blood with greater intensity in the implementation of biosynthetic processes.

Homozygous CC and VV animals have the highest pre-slaughter weight, slaughter weight and carcass weight (table 7). Higher slaughter yield (difference 1.4\%) in animals of these genotypes led to superiority in terms of the meat coefficient.

Table 7. Slaughter indicators of Kazakh Whiteheaded young bulls of different genotypes at 12-month age.

\begin{tabular}{|c|c|c|c|c|c|c|}
\hline \multirow{3}{*}{ Traits } & \multicolumn{6}{|c|}{ Gene/Genotype } \\
\hline & \multicolumn{3}{|c|}{ CAPNI } & \multicolumn{3}{|c|}{$G H$} \\
\hline & $C C$ & $C G$ & $G G$ & $V V$ & $L V$ & $L L$ \\
\hline Pre-slaughter weight, kg & $\begin{array}{c}379,2 \\
\pm 2,53 * *\end{array}$ & $\begin{array}{l}367,9 \\
\pm 1,95\end{array}$ & $\begin{array}{l}359,9 \\
\pm 1,82\end{array}$ & $\begin{array}{c}382,7 \\
\pm 2,20 * *\end{array}$ & $\begin{array}{l}371,8 \\
\pm 1,97\end{array}$ & $\begin{array}{l}362,9 \\
\pm 2,33\end{array}$ \\
\hline Slaughter weight, $\mathrm{kg}$ & $\begin{array}{c}221,1 \\
\pm 2,58 * *\end{array}$ & $\begin{array}{l}210,3 \\
\pm 2,15\end{array}$ & $\begin{array}{l}204,9 \\
\pm 2,33\end{array}$ & $\begin{array}{c}228,0 \\
\pm 1,45^{* *}\end{array}$ & $\begin{array}{l}219,0 \\
\pm 1,76 \\
\end{array}$ & $\begin{array}{l}208,9 \\
\pm 1,20\end{array}$ \\
\hline Carcass weight, $\mathrm{kg}$ & $\begin{array}{c}210,8 \\
\pm 2,07 * *\end{array}$ & $\begin{array}{l}200,7 \\
\pm 1,88\end{array}$ & $\begin{array}{l}194,4 \\
\pm 1,85\end{array}$ & $\begin{array}{c}214,9 \\
\pm 1,86^{* *}\end{array}$ & $\begin{array}{l}207,1 \\
\pm 1,62\end{array}$ & $\begin{array}{l}198,8 \\
\pm 0,58\end{array}$ \\
\hline Slaughter yield, \% & 58,3 & 57,1 & 56,9 & 59,6 & 58,9 & 57,6 \\
\hline Meat coefficient & 4,08 & 4,01 & 3,92 & 4,09 & 4,05 & 4,01 \\
\hline
\end{tabular}

The results indicate a significant effect of the genes of calpain and growth hormone on the slaughter indicators of young bulls of the Kazakh Whiteheaded breed. The presence of $C$ and $V$ alleles is associated with high values of the carcass yield and meat coefficient. 
The muscle tissue of animals of $C C$ and $V V$ genotypes for genes $C A P N 1$ and $G H$ was characterized by a higher content of protein and fat, a higher energy value compared to $G G$ and $L L$ genotypes by $0.28-2.13 \%$ and $8.7 \%$, respectively $(\mathrm{P}<0,05, \mathrm{P}<0.001)$ (table 8 ).

Table 8. Chemical analysis of m. Longissimus dorsi of Kazakh Whiteheaded young bulls of different genotypes.

\begin{tabular}{|c|c|c|c|c|c|c|}
\hline \multirow{3}{*}{ Indicator } & \multicolumn{6}{|c|}{ Genotype } \\
\hline & \multicolumn{3}{|c|}{ CAPN1 } & \multicolumn{3}{|c|}{$G H$} \\
\hline & $C C$ & $C G$ & $G G$ & $V V$ & $L V$ & $L L$ \\
\hline \multirow{2}{*}{ Moisture, \% } & 73,47 & 74,90 & 75,02 & 74,37 & 73,61 & 74,84 \\
\hline & $\pm 0,27^{*}$ & $\pm 0,29$ & $\pm 0,18$ & $\pm 0,21$ & $\pm 0,17$ & $\pm 0,24$ \\
\hline \multirow{2}{*}{ Dry matter, $\%$} & 26,53 & 25,10 & 24,98 & 25,63 & 26,39 & 25,16 \\
\hline & $\pm 0,16^{*}$ & $\pm 0,12 *$ & $\pm 0,15$ & $\pm 0,17$ & $\pm 0,09^{*}$ & $\pm 0,17$ \\
\hline \multirow{2}{*}{ Protein, $\%$} & 22,45 & 21,49 & 21,12 & 23,12 & 21,99 & 20,99 \\
\hline & $\pm 0,11 * *$ & $\pm 0,17$ & $\pm 0,14$ & $\pm 0,14 * *$ & $\pm 0,17$ * & $\pm 0,12$ \\
\hline \multirow{2}{*}{ Fat, $\%$} & $2,89^{*}$ & 2,47 & 2,38 & 2,98 & 2,79 & 2,60 \\
\hline & $\pm 0,04$ & $\pm 0,03$ & $\pm 0,03$ & $\pm 0,04 * *$ & $\pm 0,04$ & $\pm 0,02$ \\
\hline \multirow{2}{*}{ Calorie, kcal } & 1189,1 & 1111,4 & 1099,2 & 1225,3 & 1179,6 & 1121,4 \\
\hline & $\pm 7,9$ ** & $\pm 2,5 *$ & $\pm 2,5$ & $\pm 5,0 *$ & $\pm 3,6$ & $\pm 9,2$ \\
\hline
\end{tabular}

Complete characterization of the meat quality can be obtained by histological examinations of the longissimus dorsi muscle. The greatest number of muscle fibers was observed in young bulls of $C C$ and $V V$ genotypes (table 9, fig. 1). They were significantly superior to their peers in all the studied characteristics.

Table 9. Microstructural analysis of $\mathrm{m}$. Longissimus dorsi of Kazakh Whiteheaded young bulls of different genotypes.

\begin{tabular}{|c|c|c|c|c|c|c|}
\hline \multirow[b]{2}{*}{ Gene } & \multirow[b]{2}{*}{ Genotype } & \multicolumn{5}{|c|}{ Indicators } \\
\hline & & $\begin{array}{c}\text { Number of } \\
\text { muscle fibers } \\
\text { per } \mathrm{mm}^{2} \text {, pcs. }\end{array}$ & $\begin{array}{l}\text { Muscle fiber } \\
\text { diameter, } \mu \mathrm{m}\end{array}$ & $\begin{array}{c}\text { Overall } \\
\text { assessment of } \\
\text { "marbling", } \\
\text { point }\end{array}$ & $\begin{array}{c}\text { Connective } \\
\text { tissue, } \%\end{array}$ & $\begin{array}{l}\text { Eye muscle area, } \\
\qquad \mathrm{cm}^{2}\end{array}$ \\
\hline \multirow{3}{*}{ ¿ } & $C C$ & $\begin{array}{l}224,07 \\
\pm 8,31 *\end{array}$ & $\begin{array}{c}33,57 \\
\pm 0,43 * *\end{array}$ & $\begin{array}{c}31,27 \\
\pm 0,82 * *\end{array}$ & $\begin{array}{l}10,60 \\
\pm 0,31\end{array}$ & $\begin{array}{l}47,93 \\
\pm 3,65\end{array}$ \\
\hline & $C G$ & $\begin{array}{c}219,85 \\
\pm 1,96\end{array}$ & $\begin{array}{c}36,25 \\
\pm 0,59 *\end{array}$ & $\begin{array}{c}28,77 \\
\pm 0,76^{* *}\end{array}$ & $\begin{array}{l}11,53 \\
\pm 0,44\end{array}$ & $\begin{array}{l}36,04 \\
\pm 1,79\end{array}$ \\
\hline & $G G$ & $\begin{array}{c}187,25 \\
\pm 3,60\end{array}$ & $\begin{array}{l}37,80 \\
\pm 1,93\end{array}$ & $\begin{array}{l}27,75 \\
\pm 0,14\end{array}$ & $\begin{array}{c}12,73 \\
\pm 0,37 * *\end{array}$ & $\begin{array}{l}28,64 \\
\pm 3,03\end{array}$ \\
\hline \multirow{3}{*}{$\mathbb{\mho}$} & $V V$ & $\begin{array}{l}233,18 \\
\pm 5,72 *\end{array}$ & $\begin{array}{c}33,78 \\
\pm 0,17 * * \\
\end{array}$ & $\begin{array}{c}29,28 \\
\pm 0,41 * *\end{array}$ & $\begin{array}{l}10,93 \\
\pm 0,35 \\
\end{array}$ & $\begin{array}{c}52,77 \\
\pm 0,61 * *\end{array}$ \\
\hline & $L V$ & $\begin{array}{l}199,25 \\
\pm 5,41 \\
\end{array}$ & $\begin{array}{l}35,89 \\
\pm 0,47 \\
\end{array}$ & $\begin{array}{c}27,94 \\
\pm 0,99 * \\
\end{array}$ & $\begin{array}{l}12,73 \\
\pm 0,59 \\
\end{array}$ & $\begin{array}{l}40,92 \\
\pm 0,67 \\
\end{array}$ \\
\hline & $L L$ & $\begin{array}{c}177,48 \\
\pm 1,89 \\
\end{array}$ & $\begin{array}{l}40,60 \\
\pm 1,41\end{array}$ & $\begin{array}{l}25,43 \\
\pm 0,60\end{array}$ & $\begin{array}{c}14,27 \\
\pm 0,87 * *\end{array}$ & $\begin{array}{l}31,92 \\
\pm 1,51\end{array}$ \\
\hline
\end{tabular}



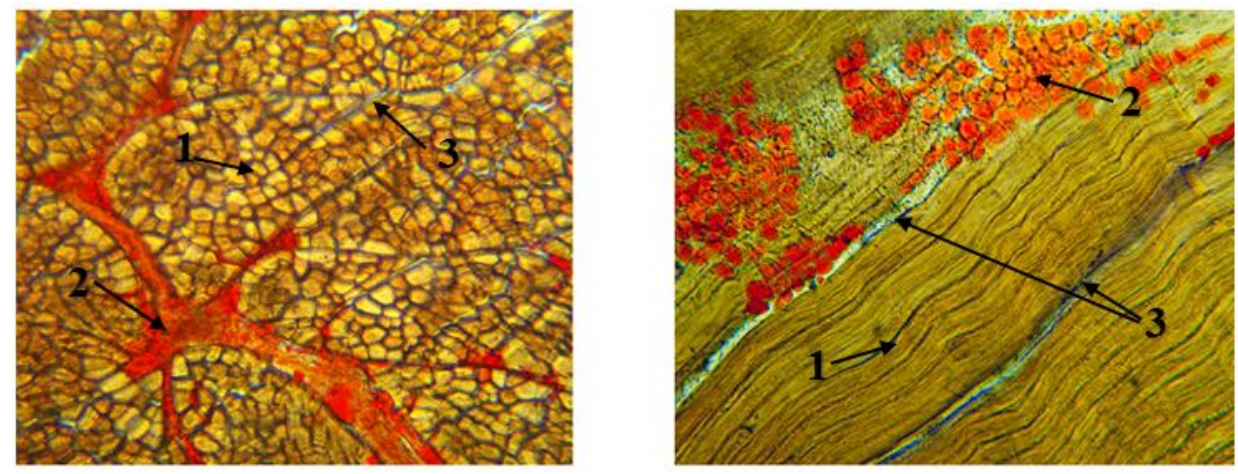

(a)
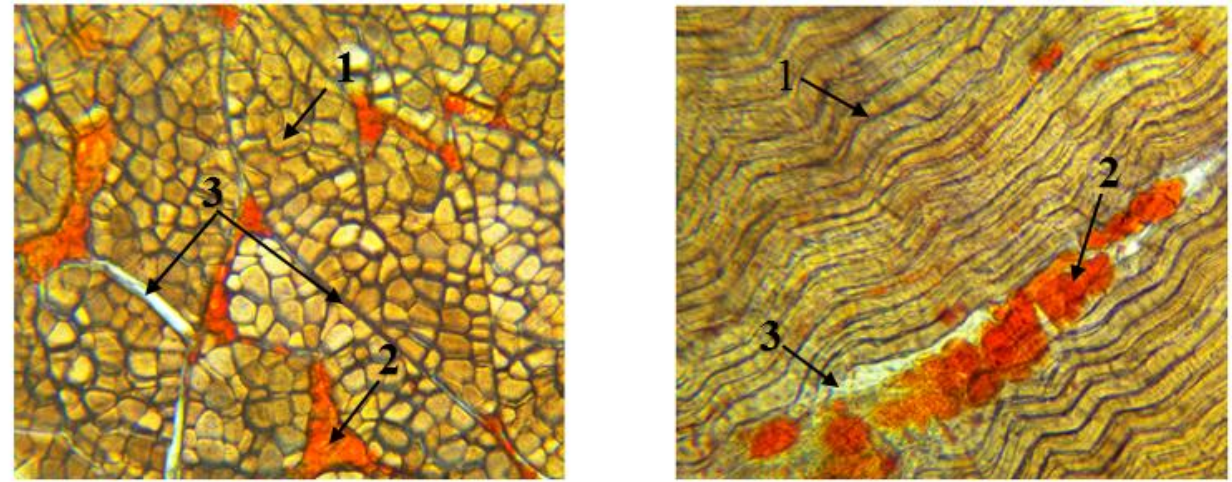

(b)

Fig. 1. Histological sections (left - transversal slice, right - longitudinal slice) $\mathrm{m}$. Longissimus dorsi of Kazakh Whiteheaded young bulls of different genotypes for the CAPN1 gene: a) - CC genotype; b) - GG genotype; 1 - muscle fiber; 2 - adipose tissue; 3 - connective tissue (staining: hematoxylin Carracci and Sudan III, enlarged 10x40).

\section{Conclusion}

Thus, significant differences have been shown in a number of economically useful traits in the Kazakh Whiteheaded cattle: milk production of cows, body weight, chemical composition of the $\mathrm{m}$. longissimus dorsi, eye muscle area, number and diameter of muscle fibers, proportion of muscle and connective tissue - between animals homozygous for the desired alleles of the CAPN1 genes (allele $C$ ) and $G H$ (allele $V$ ), with equal production costs for raising animals of different genotypes. This indicates the requirements of selection, aimed at increasing the frequencies of the desired alleles and genotypes, exist. The most valuable animals for breeding selection and further reproduction are those with the genotype where the desired alleles of both genes are present, and especially those individuals where they are in a homozygous state.

\section{References}

1. Gorlov I F, Fedunin A A, Randelin D A et al 2014 Polymorphisms of bGH, RORC, and DGAT1 genes in Russian beef cattle breeds Russ. J. Genet. 50 1302-07 https://doi.org/10.1134/S1022795414120035

2. Dzhulamanov K M, Makaev Sh A, Dubovskova M P and Surundaeva L G 2010 
Bulletin of RAAS 6 70-3

3. Lysenko NG, Kolesnik A I, Goraichuk I V, Ruban S Yu and Fedota A M 2016 Factors of experimental evolution of organisms 18 111-6

4. Makayev S A, Taiguzin RS, Lyapin O A and Fomin A V 2019 Bulletin of the Orenburg State Agrarian University 6(80) 281-5

5. Sedykh T A, Kalashnikova L A and Gizatullin R S 2019 Morfologiia 155(2) 252-3

6. Smaragdov M G 2005 Agricultural Biology 40(6) 3-8

7. Surundaeva L G and Maevskaya L A 2015 Beef cattle bulletin 4 (92) 12-5

8. Miroshnikov S A, Kosyan D B, Surundaeva L G and Rusakova E A 2017 Modern problems of science and education $6258-62$

9. Tanana L A, Vertinskaya O V, Kizilevich K O, Matyukevich D I and Lebedko E Ya 2020 Science Review 39-1 3-7

10. Barendse W, Bunch R J, Kijas J W and Thomas M B 2007 175(2) 843-53 doi: 10.1534/genetics.106.064535 Epub 2006 Dec 6 PMID: 17151246; PMCID: PMC1800623

11. Bhuiyan M S A, Kim N K, Cho Y M, Yoon D et al 2009 Livestock Science 126 292-7 https://doi.org/10.1016/j.livsci.2009.05.019

12. Ciepłoch A, Rutkowska K, Oprządek J and Poławska E 2017 Genes Genomics 39(5) 461-71 doi:10.1007/s13258-017-0525-8

13. De S, MacNeil M D et al 2004 Western Section of Animal Science Proceedings 55 958

14. Goddard M E and Hayes B J 2009 Nature Reviews Genetics 10 381-91 https://doi.org/10.1038/nrg2575

15. Kambadur R, Sharma M, Smith T P and Bass J J Genome Res 1997 7(9) 910-6 doi: 10.1101/gr.7.9.910. PMID: 9314496

16. Katoh K, Kouno S, Okazaki A et al 2008 Domestic Animal Endocrinology 34(1) 25-30 DOI: 10.1016/j.domaniend.2006.10.003

17. Lee J H, Lee Y M, Lee J Y et al 2013 Asian-Australas J. Anim. Sci. 26(10) 1359-64 DOI: https://doi.org/10.5713/ajas.2013.13248

18. Miquel M C, Villarreal E, Mezzadra C et al 2009 Genet. Mol. Biol. 32(3) 491-6 doi:10.1590/S1415-47572009000300011

19. Schenkel F S, Miller S P, Jiang Z, Mandell I B, Ye X, Li H and Wilton J W 2006 J. Anim Sci. 84(2) 291-9 doi: 10.2527/2006.842291x. PMID: 16424255

20. Sedykh T A, Gizatullin R S, Dolmatova I Yu and Kalashnikova L A 2016 Russian Agricultural Sciences 42(5) 361-6 https://doi.org/10.3103/S1068367416050207 